\title{
Law, Mansplainin', and Myth Accommodation in Campus Sexual Assault Reform
}

\author{
Chrysanthi S. Leon*
}

INTRODUCTION

On September 19, 2014, University of Delaware students organized a protest titled, "UD: End the Silence, End the Shame." Addressing more than 300 of their fellow students as well as University faculty and staff, the students shared numerous accounts of harassment by faculty members and fellow students, as well as stories of sexual assault and a lack of appropriate assistance from police and university staff. ${ }^{2}$ Testimonials during the demonstration, statements made to journalists afterwards, and evidence of an emerging pattern of "passing the harasser" by the University of Delaware (UD), ${ }^{3}$ lent urgency to calls for reform. When invited to speak at the demonstration, ${ }^{4}$ I shared the words of a student survivor who was present but

* Associate Professor of Sociology and Criminal Justice, Legal Studies, and Women and Gender Studies, University of Delaware. I thank Tamara Rice Lave and Corey Rayburn Yung for providing opportunities to share earlier versions of this work at the 2014 annual meeting of the Law and Society Association and the 2015 Kansas Law Review Symposium. I commend Abby Hall and the Kansas Law Review staff for their excellent and professional organization of the symposium. In addition, I thank my students and my colleagues at the University of Delaware and beyond for challenging my received wisdom and reassuring me that we can transcend low expectations.

1. See Meghan Jusczak, Students Stage Rally Calling for University to "Do Better" in Cases of Sexual Violence, THE REVIEW (Sept. 20, 2014), http://udreview.com/students-stage-rally-callingfor-university-to-do-better-in-cases-of-sexual-violence/ [hereinafter Do Better].

2. Id.; Jerry Rhodes, End the Silence: Hundreds Rally on The Green to Raise Awareness, UDAILY (Sept. 19, 2014, 7:05 PM), http://www.udel.edu/udaily/2015/sep/student-rally-091914.html; Elizabeth Catt et al., Editorial, Let's Keep the Conversation Going, THE REvIEW (Sept. 23, 2014), http://udreview.com/editorial-lets-keep-the-conversation-going/.

3. See Colleen Flaherty, New Job, Old Habits, InSIDE Higher Ed (Dec. 3, 2015), https://www.insidehighered.com/news/2015/12/03/did-u-delaware-pass-harasser (describing testimony in a case against a former UD professor, now facing harassment charges at San Diego State, and referencing a deal made with him when he was accused of harassment at UD that allowed him to leave quietly); see generally Faculty Senate Open Hearing on the Revised Termination and Complaint Procedures of the Faculty Welfare and Privileges Committee, UNIVERSITY OF DELAWARE (Nov. 10, 2014), https://udcapture.udel.edu/podcast/watch.php?c=571 [hereinafter Open Hearing] (transcript available at http://facsen.udel.edu/Sites/agenda/2014UDel11-10-14hearing.pdf).

4. I did not participate in any further discussion of the specific case mentioned here after the event, private counsel that I had retained for fear of retaliation advised me against it. I chose not to actively join the campus efforts to create policy change, though I have responded to requests for 
wished to remain anonymous and I urged against the rush to demonizationarguing that it only makes it more difficult to address sexual violence when we assume that the good guys among us cannot be responsible. ${ }^{5}$ Immediately following the event, a former dean called for the formation of a Faculty Senate commission on Title IX, ${ }^{6}$ the federal law that prohibits sexual-discrimination based barriers to education, including all forms of sexual violence and misconduct. ${ }^{7}$ When the UD administration appeared to dismiss concerns about institutional improprieties - passing the blame onto victims and advocates - more than 100 faculty members signed a letter in solidarity with victims, demanding the University do more. ${ }^{8}$ One might ask: why does it appear to take an egregious event or public pressure to compel universities to protect our students?

Policy change already under way at UD gained new attention after the demonstration. The Review, ${ }^{9}$ the independent student newspaper at UD, had consistently covered sexual-assault issues on campus since well before the demonstration as evidenced by the announcement of a federal Title IX investigation that preceded the protest ${ }^{10}$ and continuing coverage of the campus response, ranging from faculty senate hearings and informational meetings with Title IX officers to interviews with administrators. ${ }^{11}$ During this same time period, UD's in-house counsel proposed changes to faculty policies on termination in cases of alleged sexual harassment. ${ }^{12}$ Situated within the broader context of increased attention, such as the recent "It's On

input on a few occasions, including attending public hearings held by various bodies, some of which I will reference in this Article.

5. Statement on file with author.

6. Jagoda Dul, Faculty Senate Motions to Form Commission to Review University Sexual Violence Policies, THE REVIEW (Oct. 6, 2014), http://udreview.com/faculty-senate-motions-to-formcommission-to-review-university-sexual-violence-policies/.

7. See 20 U.S.C. $§ 1681$ (a) (2012) ("No person . . shall, on the basis of sex, be excluded from participation in, be denied the benefits of, or be subjected to discrimination under any education program or activity receiving Federal financial assistance ....”).

8. Faculty Responds: An Open Letter to the University, THE ReVIEW (Sept. 23, 2014), http://udreview.com/faculty-responds-an-open-letter-to-the-university [hereinafter Faculty Responds]. 113 faculty members at the University of Delaware signed the open letter. Id.

9. About The Review, THE REVIEW (Nov. 4, 2013), http://udreview.com/about/.

10. Meghan Jusczak, After Being Added to Federal List, University Refocuses on Sexual Violence, THE REVIEW (Sept. 15, 2014), http://udreview.com/after-being-added-to-federal-listuniversity-refocuses-on-sexual-violence/ [hereinafter University Refocuses].

11. See, e.g., Dul, supra note 6 (discussing the faculty senate's response); Do Better, supra note 1 (reporting on the demonstration).

12. See Matt Butler, Standard of Proof in Sexual Assault Cases Debated by Professors, THE REVIEW (Nov. 10, 2014), http://udreview.com/standard-of-proof-in-sexual-assault-cases-debated-byprofessors/ [hereinafter Standard of Proof] (discussing faculty senate meeting where university counsel explained new standard of proof requirements under Title IX). 
Us" campaign that was launched by the White House ${ }^{13}$ and supported by celebrities through PSAs and social media, ${ }^{14}$ both national and local discourse calls for changing our standard approach to campus sexual assault.

With significant personal and professional interest in the resulting policy responses, I read all available coverage and attended as many public meetings as possible. I quickly found myself formally "coding" the coverage, ${ }^{15}$ perhaps out of habit or to create some professional distance. I then decided to see if there was a way to turn this precipitating incident and the campus response that included the call, "\#UDo Better,", into a study of broader patterns of policy change following recognized institutional error and social protest. ${ }^{17}$

In this piece, I examine the interplay of campus protest with state policy, institutional policy, and the local implementation of policy in order to provide a nuanced account of what happens in the immediate aftermath of a burgeoning social movement. While we may interpret change as a result of public pressure and may be tempted to attribute causal influence, it turns out to be much more helpful to investigate what kinds of change we implement and how this relates to why we have not seen curtailment of sexual violence in our institutions, including universities - the subject of this case study. Put

13. Office of the Press Sec'y, FACT SHEET: Launch of "It's On Us" Public Awareness Campaign to Help Prevent Campus Sexual Assault, THE WHITE House (Sept. 19, 2014), https://www.whitehouse.gov/the-press-office/2014/09/19/fact-sheet-launch-it-s-us-public-awarenesscampaign-help-prevent-campus-.

14. Ass'N OF PUB. \& LAND-Grant Univs., IT's ON Us CAMPAign ORganizing ToOls 12 (2014), http://www.aplu.org/members/councils/governmental-affairs/CGA-library/its-on-ustoolkit/file.

15. Coding is the process by which social scientists systematically analyze narrative data. Either by hand or using software, researchers track patterns in the language, diction, and intended meaning of the texts, and then aggregate the codes into categories for further analysis. See generally

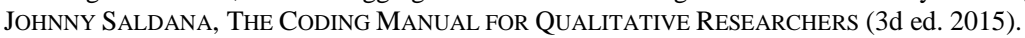

16. Do Better, supra note 1. A photograph with a sign reading \#UDo Better is on file with author.

17. Much of my research and teaching centers around the following question: Why do institutions perpetuate bad actions, support bad actors, and allow bad policy to go unchallenged? Prior publications examined the policy and practice of sex-offender punishment, with particular interest in the framing of "offenders" in opposition to "victims," a theme that carries over into my more recent work with women involved in street-based prostitution. See generally CHRYSANTHI S. Leon, Sex Fiends, Perverts, and Pedophiles: Understanding Sex Crime Policy in America (2011); Chrysanthi S. Leon \& Corey S. Shdaimah, JUSTifying Scrutiny: State Power in Prostitution Diversion Programs, 16 J. POVERTY 250 (2012); Chrysanthi S. Leon \& Corey S. Shdaimah, "First and Foremost They're Survivors": Selective Manipulation, Resilience, and Assertion Among Prostitute Women, 10 FEMINIST CRIMINOLOGY 326 (2014). My scholarly commitments and my research agenda both focus on unintended consequences of punishment policies and with documenting how policy plays out on the ground. Thus, for both personal and professional reasons, this case study made a compelling project. 
simply, this case study investigates the question, why don't we do more to address sexual violence?

In Part I, I describe my conceptual framework, bringing the scholarship on law and organizations into conversation with feminist policy interpretation. Following the conventions of sociological studies, in Part II I discuss my subject position as scholar and advocate, ${ }^{18}$ and my data and methodology. Part III uses data from the case study to examine the rhetorical and institutional strategies we see on the ground. By listening to how leaders respond to campus sexual violence, and tracking what they actually do, we can understand how much actual change is likely to occur after a public protest. In contrast to the meaningful change demanded by the community, instead we find what I identify as the impact of "legal endogeneity ${ }^{19}$ as an anticipatory response." This means that administrators and other leaders promote particular solutions that legitimize their own authority and increasingly defer to law-like structures as a way to indicate compliance, in contrast with taking up the kinds of reforms requested by experts and advocates. This kind of compliance, when combined with the perpetuation of outdated notions about sexual harassment and sexual violence also evident in this case study, satisfies only low expectations. Part IV concludes with implications for socio-legal scholars and for campussexual-assault policy.

\section{CONCEPTUALIZING POLICYMAKING IN RESPONSE TO PRESSURE FOR CAMPUS SEXUAL ASSAULT REFORM}

\section{A. Organizations}

Classical social theory has examined the increasing specialization of social institutions, ${ }^{20}$ including the progression towards what Max Weber

18. As discussed below, my approach is that of standpoint theory. See, e.g., Pamela Nilan, "Dangerous Fieldwork" Re-Examined: The Question of Researcher Subject Position, 2 QuALITATIVE RES. 363, 364 (2002), http://utsc.utoronto.ca/ kmacd/IDSC10/Readings/Readings/Positionality/reflexivity.pdf (describing the ethnographic researcher's subject-position as one featuring a "discourse of immersion, reflexivity and rapport").

19. Legal endogeneity is "a powerful process through which institutionalized organizational structures influence judicial conceptions of compliance with antidiscrimination law. It finds that organizational structures . . . become symbolic indicators of rational governance and compliance with antidiscrimination laws, first within organizations, but eventually in the judicial realm as well." Lauren B. Edelman et al., When Organizations Rule: Judicial Deference to Institutionalized Employment Structures, 117 AM. J. Soc. 888, 888 (2011). For further explanation of the term legal endogeneity, see infra text accompanying note 45.

20. See generally Emile Durkheim et al., Durkheim AND the LaW (Steven Lukes \& 
calls legal-rational forms of authority as embodied in the idealized bureaucracy (not meant as a slur in Weber's usage). ${ }^{21}$ Authority that is organized around clear rules-with the possibility of appeal-and with limits to the discretion of those in power, marked some of the advantages Weber perceived to be in contrast with power that is passed down by tradition (e.g., royalty) or gained because of the charisma of the particular leader (e.g., despots). ${ }^{22}$ Weber believed that, as a form of institution, bureaucracies are more stable, open to challenge from those with less power, and more capable of handling complexity than institutions whose power is based on charisma or tradition. ${ }^{23}$ However, Weber recognized that bureaucracies would have potential pitfalls, such as granting too much power to "petty bureaucrats" because of their specialized knowledge over their particular divisions, which in turn would create situations in which organizational leaders would defer to petty bureaucrats when perhaps they should not. ${ }^{24}$ Certainly there is evidence for this across the board, and even in the area of sexual violence. As I have written elsewhere with colleagues regarding a series of recent sensational cases of ongoing child abuse covered up by institutions, our complicated laws and policies, interpreted through bureaucracy, enable those responsible to "diffuse the responsibility" and allow abuse to continue. ${ }^{25}$

\section{Organizational Deviance?}

An emerging body of research explores continued sexual abuse within institutions such as the Catholic Church, ${ }^{26}$ and within athletic programs such as those of Pennsylvania State University. ${ }^{27}$ In a recent study, M. Kristen

Andrew Scull eds., 1983).

21. MAX Weber, ECONOMY AND SOCIETY: AN OUTLINE OF INTERPRETIVE SOCIOLOGY 21726, 271-301 (Guenther Roth \& Claus Wittich eds., Ephraim Fischoff et al. trans., 4th ed. 1968).

22. Id. at $271-301$.

23. Id.

24. Id.

25. Susan L. Miller, M. Kristen Hefner \& Chrysanthi S. Leon, Diffusing Responsibility: A Case Study of Child Sexual Abuse in Popular Discourse, 37 CHILD. \& YouTH SERVS. REV. 55, 56 (2014).

26. See generally Karen J. Terry et AL., John Jay Coll. Res. Team, The Causes And Context of SeXual Abuse of Minors by CATHolic PRIESTS in the United States, 1950-2010 (2011), http://www.usccb.org/issues-and-action/child-and-youth-protection/upload/The-Causes-andContext-of-Sexual-Abuse-of-Minors-by-Catholic-Priests-in-the-United-States-1950-2010.pdf. This report was presented to the United States Conference of Catholic Bishops. Id.

27. See generally FreEH SPORKIN \& Sullivan, LLP, REPORT OF THE SPECIAL INVESTIGATIVE Counsel Regarding the Actions of the Pennsylvania State University Related to the Child SeXuAl ABuse COMmitTed By Gerald A. SANDUSKy (2012), http://healthequity.pitt.edu/3956/1/REPORT_FINAL_071212.pdf. 
Hefner interviewed a variety of organizational actors involved in the eventual disclosure and prosecution of ongoing and heinous sexual abuse by a pediatrician against numerous infants and children. ${ }^{28}$ In keeping with what we know about religious institutions and college athletics (both of which demonstrate that respect for authority and denial of the worth of victims contribute to allowing sexual abuse to go unchecked), Hefner argues that the concept of organizational deviance is important to understanding why so many people were aware of the pediatrician's abuse, and yet the abuse continued for several years. ${ }^{29}$ Building on the broader literature, which demonstrates that decision-making at various levels in the justice system is shaped by perceptions of who victims are and where they are from, ${ }^{30}$ Hefner finds that professional norms about the reliability of victims contributed to the long delay in seeking the warrant that eventually led to arrest and conviction. $^{31}$

While organizational deviance and myths about victims and "real' rape" ${ }^{, 32}$ no doubt play a role in many contexts, and likely did in this case study as well, it is important to be context-specific. The evidence in Part II distinguishes the institutional response from organizational deviance since what I describe as "legal endogeneity in anticipation" reflects compliance, not deviance. However, before introducing these concepts I began with an essential socio-legal framework.

\section{B. The Force of Law}

Law has a peculiar hold on the social imagination, and extends its tentacles into social institutions in pervasive and tenacious ways. In The Force of Law, Pierre Bourdieu examines how and why law has the power it does, what makes law's power possible and what sustains it. ${ }^{33}$ I focus here on his insights into how legal experts defend their interpretive authority and

28. M. Kristen Hefner, "It's Always Silence That Causes the Most Damage": A Case Study of the Institutional Responses to the Dr. Earl Bradley Child Sexual Abuse Case (2016) (unpublished Ph.D. dissertation, University of Delaware).

29. Id. at 3-4; see also Miller, Hefner \& Leon, supra note 25, at 56-57.

30. See generally Lisa Frohmann, Convictability and Discordant Locales: Reproducing Race, Class, and Gender Ideologies in Prosecutorial Decisionmaking, 31 L. \& Soc'Y REV. 531 (1997) (examining data pertaining to prosecutors' work in sexual-assault units).

31. Hefner, supra note 28, at 11.

32. Martha R. Burt, Rape Myths, in CONFronting RaPE AND SeXual Assault 130 (Mary E. Odem \& Jody Clay-Warner eds., 1998).

33. Pierre Bourdieu, The Force of Law: Toward a Sociology of the Juridical Field, 38 HASTINGS L. J. 805, 816 (Richard Terdiman trans., 1987). 
on the impact of what he calls "miscognition." these core insights, I describe socio-legal research that focuses on the force of law on organizations.

\section{Battle of Experts and Interpretive Authority}

Bourdieu reveals law as a grounded social practice that is socially constructed by individuals, but that also follows patterns at the institutional level that make it appear rational. He describes the way those with a professional stake in law's interpretation defend their territory, and calls for research that examines how this plays out in specific contexts:

The tendency to accentuate the syntax of the law is rather characteristic of theoreticians and professors, while attention to the pragmatic side is more likely in the case of judges. But a social history should also consider the relation between the variations in the relative power of these two polar orientations concerning juridical work, variations which depend upon place and historical moment, and the variations in the relative power of the two groups within the power structure of the juridical field. ${ }^{35}$

While legal experts may vary their particular focus, and may at times disagree, Bourdieu emphasizes that it is crucial for these experts to exclude those outside the legal profession:

The establishment of properly professional competence, the technical mastery of a sophisticated body of knowledge that often runs contrary to the simple counsels of common sense, entails the disqualification of the non-specialists' sense of fairness, and the revocation of their naive understanding of the facts, of their "view of the case.,"

In order for law to maintain its power, it must be something beyond common sense that requires specialist interpretation.

\section{Miscognition}

Further, law not only functions in practice to further the interests of those already in power by reinforcing existing social divisions and social structures,${ }^{37}$ but also by preserving its legitimacy through what Bourdieu

\footnotetext{
34. Id. at 813,817 .

35. Id. at 822 .

36. Id. at 828 .

37. Id. at 838. "Law consecrates the established order by consecrating the vision of that order
} 
calls miscognition. ${ }^{38}$ As Bourdieu's translator explains, miscognition "implies the inherent advantage of the holders of power through their capacity to control not only the actions of those they dominate, but also the language through which those subjected comprehend their domination." 39 Legal language mystifies and obfuscates, and requires specialist interpreters, but in doing so preserves its own power and autonomy. ${ }^{40}$

\section{Governance, Law, and Organizations}

The quest to maintain an appearance of legitimacy extends beyond the legal realm. Neo-institutional scholarship examines why institutions mimic each other as they evolve over time, and frequently finds that pressures towards isomorphism (the development of similar features) are often grounded in the desire to appear legitimate, rather than for technical reasons such as maximizing efficiency or otherwise achieving substantive outcomes. ${ }^{41}$

A related strand of research in law and society documents the cooptation of legalistic structures. Some work focuses on critique, pointing out what is lost when internal organizational processes mimic law and, in so doing, undermine the power of law to achieve change. ${ }^{42}$ Analyzing women who experienced sexual harassment at work, Anna-Maria Marshall finds that workplace grievance procedures not only prevent women from asserting their rights, but also actually change the legal apparatus around sexual harassment law in ways that consolidate the employer's power:

According to the women who encountered sexual conduct at work, managers interpreted the policy in ways that discouraged complaints, adopting an adversarial posture that challenged rather than supported

\footnotetext{
which is held by the State." $I d$.

38. Id. at 813 .

39. Id.

40. Id. at 814

41. See, e.g., Ashley T. Rubin, A Neo-Institutional Account of Prison Diffusion, 49 L. \& SOC'Y REV. 365, 373-76 (2015) (explaining neo-institutional approach and isomorphism and applying this approach to state institutions). Drawing on Foucault's analysis of governmental power, Rubin finds that many states initially built prisons in order to counteract their image problems: by adopting the congregate style prison (then the "model" of modern governance), states could establish their legitimacy. Id. at 378-83.

42. See, e.g., Rebecca L. Bordt \& Michael C. Musheno, Bureaucratic Co-Optation of Informal Dispute Processing: Social Control as an Effect of Inmate Grievance Policy, 25 J. RES. CRIM. \& DELINQ. 7, 22-23 (1988) (finding that inmate-grievance procedures, which were originally intended to justly resolve disputes, ended up being used as new means for social control—not to further the law).
} 
women seeking relief. ${ }^{43}$

Marshall's work engages with a discussion among socio-legal scholars about the promise and limitations of law as a vehicle for social change. ${ }^{44}$

Focused on organizations, scholars describe the process by which judges increasingly defer to law-like structures within organizations:

Legal endogeneity theory articulates the process through which everyday organizational practices, routines, and structures subtly influence legal thinking, legal categories, and legal logic. It suggests that as certain organizational structures become widely institutionalized and taken for granted as rational forms of organizational governance, legal actors and legal institutions become increasingly likely to associate those structures with legal compliance. ${ }^{45}$

Edelman and colleagues have documented this process among judges over time. For example, in their analysis of 1,024 federal, employmentdiscrimination opinions from 1965 to 1999 they describe three stages of legal endogeneity: (1) reference, (2) relevance, and (3) deference. ${ }^{46}$ Edelman focuses on equal employment opportunity (EEO) law because that area of law is characterized by ambiguous statutory language and contested politics. $^{47}$

This study focuses on the sexual harassment and assault provisions of Title IX, ${ }^{48}$ which is similarly an area of emerging standards, contradictions, and ambiguity. ${ }^{49}$ In keeping with Edelman's body of work on legal

43. Anna-Maria Marshall, Idle Rights: Employees' Rights Consciousness and the Construction of Sexual Harassment Policies, 39 L. \& SoC'Y REV. 83, 99 (2005)

44. See Kristin Bumiller, Victims in the Shadow of the Law: A Critique of the Model of Legal Protection, 12 Signs 421, 425-28 (1987) (describing, as a foundational piece, why victims often elect not to use legal tools in part due to recognition that they will not further their own interests but often will elicit further problems).

45. Edelman et al., supra note 19 , at 890 .

46. Id. at 893 .

47. Id. at 891 .

48. 20 U.S.C. $\$ \S 1681-88$ (2012).

49. On April 4, 2011, the U.S. Department of Education's Office of Civil Rights released a "Dear Colleague" letter meant to update, clarify, and enhance the application of Title IX on college campuses. See Letter from Russlyn Ali, Assistant Sec'y for Civil Rights, U.S. Dep't of Educ., to Title IX Coordinators (Apr. 4, 2011) [hereinafter Dear Colleague], http://www2.ed.gov/about/offices/list/ocr/letters/colleague-201104.pdf (promulgating new guidance to help schools meet their obligations under Title IX). This was followed in 2014 by a Q\&A document. Catherine E. Lhamon, Assistant SeC'y for Civil Rights, U.S. DeP'T OF EduC., Questions AND ANswers ON Title IX AND SEXual Violence (2014), http://www2.ed.gov/about/offices/list/ocr/docs/qa-201404-title-ix.pdf. While working well as a symbolic sign of federal support for victims, along with the "We've Got Your Back" campaign, these documents have been extremely confusing to those tasked with implementation. See, e.g., 
endogeneity, I will demonstrate in this case study that as certain aspects of Title IX policy are recognized as symbolic improvement, we see little to no consideration of the adequacy of how these protections play out on the ground level. ${ }^{50}$

\section{Myth Accommodation}

Building on concern with how implementation of policy may undermine its purported goals, I next turn to a framework adapted from public health. The framework for public-health-policy evaluation promoted by the U.S. Office of Women's Health is a gender-integration continuum that emphasizes the centrality of gender in understanding how well meaning policies may work in practice. ${ }^{51}$ Gender-informed analysis pays careful attention to how proposed goals and interventions may exploit traditional gender roles and may actually constrain or harm its intended beneficiaries (gender exploitative), as well as those that work around existing gender beliefs and perpetuate them (gender accommodating), and those that transform gender relations (gender transformative). ${ }^{52}$ I adapt this framework

NAT'L CTR. FOR Higher Educ. Risk MGMT., NCHERM ReACTION to DEAR Colleague TitLe IX

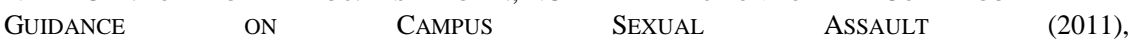
https://www.ncherm.org/documents/NCHERMReactiontotheDearColleagueLetter4.6.11.pdf (characterizing the Dear Colleague letter as formalizing policy the OCR had used campus-bycampus for years).

50. For other work documenting the institutional tendency to cover itself, see Arlen Z. Jones, Beyond "Bad Apples," More Than a Scandal: A Cross-Disciplinary Analysis of Institutionalized Organizational Deviance 17-18 (2011) (unpublished manuscript) (on file with author), stating:

[W] hen a rational bureaucracy is able to change the institutional environment, such that the myths and ceremonies expected of it are those of its own cultural and organizational creation, a feedback loop ensues. The deviant organization that manipulates its symbolic indicia to appear more efficient, reliable, legible, accountable and, most of all, productive is societally positioned to bring pressure to bear on other organizations in the institutional environment. The bloated scores and manufactured success of the deviant organization changes societal expectations of what an organization can do, which reinforces the myths and ceremonies that push the bureaucratic mediation of organizational function. Now, seen as industry trailblazers, the organization has its legitimacy and autonomy linked to the bureaucratic production of proxy measurements of efficacy. . . Essentially, deviant organizations fail when they come to believe their own hype at the same time that they start smoking their own dope.

51. Status of Women Canada, Gender Based Analysis: A Guide for Policy-Making

http://www.pacificwater.org/userfiles/file/IWRM/Toolboxes/gender/gender_based_analysis.pdf; see also INTERAGENCY GENDER WORKING GRP., GENDER EQUALITY CONTINUUM TRAINING MODULE 2, http://www.igwg.org/igwg_media/Training/FG_GendrIntegrContinuum.pdf (reproducing the Gender Equality Continuum Tool).

52. Joan Marie Kraft et al., An Evidence Review of Gender-Integrated Interventions in Reproductive and Maternal-Child Health, 19 J. HeALth Coмm. 122, 124-25 (2014). 
and build on the "rape myths" accommodation," the use of rhetorical strategies that minimize the existence or significance of sexual misconduct itself as a way to prevent threats to the institutional status quo.

\section{DATA AND METHODOLOGY}

\section{A. Feminist Inquiry}

Qualitative inquiry grapples with conventional views of formal objectivity in the collection and analysis of research data. ${ }^{54}$ Although scholars strive to recognize their influence on the research process, few claim utter emotional detachment. ${ }^{55}$ Instead, we engage in a series of practices that promote reflexivity in order to monitor the impact on the data of our subject position as researcher. ${ }^{56}$ These practices include engagement with our potential bias during the data collection process; for example, in the form of memos and peer debriefing intended to avoid cherry picking (i.e., using only confirmatory data), as well as disclosures such as this one. ${ }^{57}$ As I will detail further in the data section below, this work is profoundly informed by my experience as a faculty member on campus during the rise, cresting, and falling of student and faculty discourse as well as institutional policymaking around campus sexual assault on my mid-Atlantic university campus, which serves as the focus for this extended case analysis. ${ }^{58}$ Further, I take the explicit position of a feminist scholar and advocate, committed to reducing sexual violence in empirically grounded ways. ${ }^{59}$

53. Rape myths are widely held but empirically false attitudes and beliefs about rape and its victims that correspond with a willingness to assign blame to sexual assault survivors. Burt, supra note 32 , at 129 .

54. See Nilan, supra note 18 , at 370.

55. See Kari Lerum, Subjects of Desire: Academic Armor, Intimate Ethnography, and the Production of Critical Knowledge, 7 QUALITATIVE INQUIRY 466, 472 (2001) (explaining the idea of emotional detachment in sociological research).

56. See generally Nilan, supra note 18, at 369-74.

57. M. Q. Patton, Qualitative Research \& Evaluation Methods $64-66$ (3d ed. 2002) (explaining reflexivity and providing examples).

58. For background context on national fervor around addressing campus sexual assault, see generally Aya Gruber, Anti-Rape Culture, 64 U. KAN. L. REV. 1025 (2016).

59. LEON, supra note 17 , at 253 . In tandem with utilizing the described qualitative-analytic strategies that address bias and validity, my work reflects my first-hand experiences. Rather than a detached observer, this mode of qualitative research recognizes that immersion and rapport can often be best achieved through participation. PATTON, supra note 57, at 129-31. In fact, participation may be seen as integral, as Sandra Harding describes in her account of the history of feminist standpoint theory:

As science, standpoint projects were to see "beneath" or "behind" the dominant sexist 
In the framing of my work I emphasize the aspect of standpoint theory which prioritizes listening to those who are primarily impacted by the policy under study. ${ }^{60}$ In this case study, this means seeking out the public expressions of those who are subject to the policies ${ }^{61}$ including: student survivors; sexual assault practitioners who work with sexual assault survivors; the bureaucracy that administers the campus response; and faculty who are generally understood to be mentors and advocates for their students. $^{62}$

\section{B. Case Study Approach}

Grounded in socio-legal studies, I use an extended case analysis to understand law in action, showcasing "interest in cultural analysis: in the ways legal institutions and actors create meanings, the impact of these meanings on surrounding social relationships, and the effect of the cultural

and androcentric ideologies that shaped everyone's lives to the relations between, on the one hand, the actuality of women's everyday lives and, on the other hand, the conceptual practices of powerful social institutions ... P. Political engagement, rather than dispassionate neutrality, was necessary to gain access to the means to do such research . .

. . Last but not least, political struggle itself produced insight. The more value-neutral a conceptual framework appears, the more likely it is to advance the hegemonous interests of dominant groups, and the less likely it is to be able to detect important actualities of social relations .... We need not-indeed, must not—choose between "good politics" and "good science," standpoint theorists argued, for the former can produce the latter.

Sandra Harding, Standpoint Theory as a Site of Political, Philosophic, and Scientific Debate, in THE Feminist Standpoint Theory Reader: Intellectual \& Political Controversies 1,6 (Sandra Harding ed., 2004). Feminist standpoint theory can be described as methodological, epistemological, and in many other ways. $I d$. at 4.

60. Harding, supra note 59, at 2, 7 .

61. In addition, in my own work I argue that rigorous and ethical research and advocacy requires us to listen to those in other positions and beyond. The problematic tendency not to listen to certain groups is tied to the similar problematic tendency to favor a dichotomous approach that pits one type or side against the other, eliding the more messy reality that lacks clear boundaries. See, for example, the victim versus offender approach, which characterizes much of United States criminal justice policy debate. LEON, supra note 17, at 253 . I am fortunate to have participated in the outstanding 2015 Kansas Law Review symposium, which provided an opportunity for principled disagreement, which in turn improves the quality of my own work. I thank my fellow scholars and the Law Review for providing the opportunity.

62. While some faculty are explicitly advocates for student survivors, e.g., Support Survivors, FACULTY AGAINST RAPE, http://www.facultyagainstrape.net/support-survivors/ (last visited Feb. 4, 2016), faculty in general interpret their role as one of mentorship. See Kathryn A. Branch et al., Professors' Experiences with Student Disclosures of Sexual Assault and Intimate Partner Violence: How "Helping” Students Can Inform Teaching Practices, 6 FEMINIST CRIMINOLOGY 54, 61-65, 6770 (2011) (discussing study of student-professor disclosures and detailing how professors responded, largely through mentoring). For some faculty, the recent elevation of campus sexual assault within the media and other realms has led to a new sense of identification with a more explicit advocacy position. See, e.g., Faculty Responds, supra note 8. 
framework on the nature of legal procedures themselves."63 Numerous socio-legal scholars examine the contexts and impacts of doctrinal law; ${ }^{64}$ an approach that is especially needed when law is administrative or deeply influenced by administrative interpretation. ${ }^{65}$

\section{Case Study: Campus Sexual Assault Policy Reform}

This case study consists of content analysis of public statements as well as other descriptions of campus events surrounding sexual harassment and assault at my university. During the past year, one of these cases resulted in a large campus protest at UD and significant media and local attention. ${ }^{66}$ UD's campus activism engages with national conversations about the handling of complaints brought under the umbrella of Title IX, as well as with an ongoing investigation of the University for allegedly mishandling a prior case (with which I am familiar but not involved). ${ }^{67}$

Available data includes public statements that were reported in media and in other venues. While I draw on these, the most discrete sources of data to analyze for the purpose of this project are the series of articles in the UD Review and transcripts of two UD faculty hearings devoted to debating proposed changes in the procedures for responding to sexual-harassment claims made against faculty under the governance of the Committee for Faculty Welfare and Privileges. ${ }^{68}$

63. Sally Engle Merry, Anthropology, Law, and Transnational Processes, 21 AnN. Rev. ANTHROPOLOGY 357, 360 (1992).

64. See, e.g., David M. Engel, Perception and Decision at the Threshold of Tort Law: Explaining the Infrequency of Claims, 62 DePAUL L. ReV. 293 (2013); Katherine Beckett, Culture and the Politics of Signification: The Case of Child Sexual Abuse, 43 Soc. Probs. 57 (1996).

65. For examples of administrative areas where research into the impact of doctrinal law is particularly necessary, see Keramet Reiter, Comment, Experimentation on Prisoners: Persistent Dilemmas in Rights and Regulations, 97 CAL. L. REV. 501 (2009), discussing prison-administration regulations and their failings, Arthur McEvoy, Freedom of Contract, Labor, and the Administrative State, in THE STATE AND FREEDOM OF CONTRACT 198 (Harry N. Scheiber ed., 1998), examining the impact of labor laws, and Robert A. Kagan, Regulatory Justice: IMPlementing A WAGEPRICE FREEZE (1978), evaluating the workings of the administrative legal process.

66. Do Better, supra note 1.

67. University Refocuses, supra note 10 . While my experience as a faculty mentor for students who have sought help with sexual harassment or who were accused of sexual assault is an unavoidable background to my interpretation, it is not the basis of this analysis. To be very clear: in this Article I do not comment on the most publicized case in which I was involved. That is both to avoid legal liability and to respect the privacy of the accused, the administration, and the victim. However, as a side note, it should be known that the comments I made in the referenced media coverage were made with the permission of the involved student. Data used for content analysis herein is either publically available, as in the case of faculty senate proceedings, or consists of public statements made by university officials.

68. For case studies such as this Article, university meetings and other field notes are 


\section{Analytic Approach}

My analysis of three levels of response to this recent campus activism relies on Foucault's concept of "governmentality." "Specifically, I examine the rhetorical and institutional strategies evident in state legislative responses, campus policy responses, and the interpretation and implementation of the Department of Education's Office of Civil Rights' guidance on Title IX. ${ }^{70}$ Using a process of inductive coding, ${ }^{71}$ I read and reread the articles and transcripts and identified the ways in which commenters talked about "the law," their framing of sexual assault as a "problem," as well as the framing of related institutional responses as "problems" or as "solutions."72 My analysis of the senate proceedings focused on the roleplaying of lawyers, administrators, and faculty senators, facilitated by my insider knowledge of many of those who spoke during the hearings. ${ }^{73}$

\section{CASE STUdy: Myth ACCOMODATION, MANSPLAININ', AND LEGAL ENDOGENEITY IN CAMPUS SEXUAL-ASSAULT-POLICY REFORM}

\section{A. Governmentality Across Three Levels of Reform Endeavors}

National and local attention has recognized campus sexual assault as a

especially important sources of data. See Theresa Castor \& François Cooren, Organizations as Hybrid Forms of Life: The Implications of the Selection of Agency in Problem Formulation, 19 MGMT. Comm. Q. 570, 582 (2006) (describing a case study of faculty senate proceedings); see also Theresa Castor, 'It's just a Process': Questioning in the Construction of a University Crisis, 11 DisCOURSE STUD. 179, 183-84 (2009) [hereinafter University Crisis] (describing a case study using field notes).

69. Michel Foucault, The Foucault EfFect: Studies in Governmentality 102-03 (Graham Burchell et al. eds., 1991) [hereinafter FouCAULT EFFECT] (defining his usage of governmentality); see also generally Michel FoucAult, DisciPLINE AND PUNISH: THE BIRTH OF THE PRISON (Alan Sheridan trans., Vintage Books 2d ed. 1995) (1977).

70. For legal analysis of Title IX and its applicability to campus sexual assault, see Gruber, supra note 58; Sarah L. Swan, Between Title IX and Criminal Law: Bringing Tort Law to the Campus Sexual Assault Debate, 64 U. KAN. L. REv. 961, 961-66, 968-69 (2016); Corey Rayburn Yung, Is Relying on Title IX a Mistake? 64 U. KAN. L. REV. 891, 891-902 (2016); Tamara Rice Lave, Campus Sexual Assault Adjudication: Why Universities Should Reject the Dear Colleague Letter, 64 U. KAN. L. Rev. 913, passim (2016); Katharine K. Baker, Campus Sexual Assault as Sexual Harassment: A Defense of the DOE, 64 U. KAN. L. REV. 861, passim (2016).

71. See PATtON, supra note 57, at 453, 462-66 (discussing inductive analysis and explaining what coding is as well as how to code).

72. See Jonathan Simon, Governing Through Crime: How the War on CRime TRANSFORMED AMERICAN DEMOCRACY AND CREATED A CUlture OF FEAR 17 (2007) (explaining that we now "govern through crime," using crime in a historically novel way to "interpret and frame all forms of social action as a problem for governance").

73. University Crisis, supra note 68, at 179 (describing analysis of faculty senate proceedings). 
problem that calls out for governmental response. In the following, I use my case study to describe how state legislators, university policymakers, and administrative bureaucrats have promoted particular solutions that legitimize their own authority and utility. ${ }^{74}$ While I distinguish three levels of policy response, in practice there is overlap between and interplay among them.

\section{State Legislative Response and a Conflict of Experts: Mandated Reporting to Non-University Police}

I begin with a brief look at the most discrete response to doing more, which took place at the level of state legislative response, and is thus pure policy as opposed to the more practical issues of implementation discussed later. Following a campus screening of the controversial documentary, The Hunting Ground ${ }^{75}$, that took place the semester after the demonstration, several Delaware legislators proposed legislation to require that sexual assault on campus be reported to the local police, regardless of the wishes of the victim. ${ }^{76}$ While undoubtedly well meant, ${ }^{77}$ this policy suggestion is not grounded in the experience of either those who work directly with sexual assault survivors or those of survivors themselves. When counseling staff and hotline volunteers who respond to sexual assault on our campus met with the legislators to discuss their concerns, they were dismissed and felt ridiculed: "According to one of the student advocates, one lawmaker told the group that a victim who doesn't report her rape is to blame for any other assaults committed by her attacker., ${ }^{, 78}$ A national feminist blog highlighted

74. See FoucAult EFFECT, supra note 69, at 103 (arguing that the continued existence of the state is due to the state's ability to make itself the only recourse, the "the only real space for political struggle"); FOUCAULT, supra note 69, at 333. For application, see, for example, SIMON, supra 72, at 77-90, 105-06, describing shifts in how the U.S. has governed, moving from the citizen farmer as ideal subject to the crime victim as ideal subject, and discussing the related shifts in policies and other governmental and community interventions, and LEON, supra note 17, at 253, describing shifts over time in understandings of who commits sexual violence, what causes it, and the kinds of policies that are needed to address it.

75. John Offredo, Bill Requires Universities to Report Assaults to Police, DELAWARE ONLINE (Apr. 1, 2015, 11:54 AM), http://www.delawareonline.com/story/news/local/2015/03/31/billrequires-universities-report-assaults-police/70741702/.

76. H.B. 1, 148th Gen. Assemb., Reg. Sess. (Del. 2015); see also Del. House of Reps., Synopsis of Original Bill, http://legis.delaware.gov/LIS/lis148.nsf/2bede841c6272c888025698400433a04/ffd34a43293f7f7a85 $257 \mathrm{e} 050059 \mathrm{c} 2 \mathrm{dd}$ ?OpenDocument\&Highlight=0,campus,sexual,assault (last visited Feb. 25, 2016).

77. I attended the campus screening on March 11, 2015, and observed the enthusiasm and concern of the lawmakers in attendance, who were greeted by name by the event organizers.

78. Dana Bolger, Paternalistic Delaware Women Lawmakers Fight Campus Rape Survivors on Bill, FEMINISTING, http://feministing.com/2015/10/08/paternalistic-delaware-women-lawmakersfight-campus-rape-survivors-on-bill/ (last visited Jan. 28, 2016). 
the story in a piece titled Paternalistic Delaware Women Lawmakers Fight Campus Rape Survivors on Bill. ${ }^{79}$

This gap between professionals, campus counselors, as well as those directly affected - survivors - on one side and the legislators on the other reveals the significance of where we locate the problems, solutions, and sources of authority most important to us - the essence of Foucault's governmentality approach. ${ }^{80}$ For the legislators, the most pressing problem was a perception of victims' noncompliance with expectations for reporting crime and participating in the justice process. ${ }^{81}$ It is not clear which source of authority they do rely on, other than their own, but it is clear they dismiss outright the authority of counseling professionals and of victims. ${ }^{82}$ As legislators, ${ }^{83}$ it is no surprise that their solution would be to pass a new law that would require third parties to report to police ${ }^{84}$ similarly, the attempt to legislate our way out of a painful social problem also implicates Bourdieu's insights into how experts maintain their territory. Unfortunately, voluminous evidence demonstrates how much trouble comes out of good intentions that lack empirical grounding. ${ }^{85}$ Specifically, evidence has shown that requiring reporting can have unintended consequences that further victimization rather than addressing it, which in turn prevents healing. ${ }^{86}$ At

\footnotetext{
79. Id.

80. See Foucault EFFECT, supra note 69, at 87-104 (detailing the concept of governmentality).

81. See Bolger, supra note 78.

82. See supra note 78 and accompanying text.

83. For more on the politics of crime fighting, see generally SIMON, supra note 72; and for the politics of sex-crime fighting, see generally Beckett, supra note 64; and LEON, supra note 17.

84. Requiring third parties to report to police regardless of a victim's wishes is called mandated reporting. For a discussion of its efficacy, see Frank Ainsworth, Mandatory Reporting of Child Abuse and Neglect: Does It Really Make a Difference?, 7 CHILD \& FAM. SOC. WORK 57 (2002). Mandated reporting originally developed with regard to reporting of possible child abuse or neglect by responsible professionals who may be in contact with children. See C. Henry Kempe et al., The Battered-Child Syndrome, 181 JAMA 17 (1962), reprinted in 251 JAMA 3288, 3294 (1984) (instructing physicians to report suspected abuse to authorities regardless of their level of confidence in the diagnosis of child abuse); see also BARBARA J. Nelson, MAKING AN ISSUE OF CHILD ABUSE: Political Agenda SETTiNg For Social Problems 76 (1986) (discussing early adoption of child abuse laws in the United States). The popularity of this intervention spread in a variety of ways. For example, in many states all adults are now required by law to report suspected child abuse or neglect. See Children's Bureau, Mandatory Reporters of Child Abuse and Neglect (2014), https://www.childwelfare.gov/pubPDFs/manda.pdf (listing state child-abuse, mandatoryreporting statutes). In this Article, I explore the extension of mandated reporting of abuse of adults, i.e. college students reported on college campuses to other adults such as faculty and staff.

85. LEON, supra note 17.

86. See generally MurRay Levine \& Howard J. Doueck, The IMPaCt of Mandated REPORTING ON THE THERAPEUTIC PROCESS: PICKING UP THE PIECES (1995); see also Robert Deisz et al., Reasonable Cause: A Qualitative Study of Mandated Reporting, 20 CHILD ABUSE \& NEGLECT
} 
$\mathrm{UD}$, there has not been a formal venue for professionals and survivors to express their alternative conceptualization of problems and solutions, partly related to the fact that the professionals are located within a larger institution that may not empower them to argue publicly with policymakers. Student survivors, however, have used the media to publicize their concerns. ${ }^{87}$ These students are working with a legislator to promote alternatives that would focus on addressing the reasons why victims are reluctant to use the criminal justice system, rather than on coercing their involvement in it. Therefore, we can note the difference between the targets of governance: for the legislators, it is the victims who require intervention in the form of coercion; whereas for the professionals and survivors, the preferred target is a system that has shown evidence of antagonism towards victims, especially if they are intoxicated or otherwise viewed as unreliable. ${ }^{88}$

275, 276-77, 284-86 (1996); Ainsworth, supra note 84, at 62-63. In addition, clinicians have consistently raised ethical concerns about mandated reporting focusing on the harm it may have on the victim/client's trust in the reporting clinician, as well as its impact on removing control or agency from the victim/client. See Lawrence R. Faulkner, Mandating the Reporting of Suspected Cases of Elder Abuse: An Inappropriate, Ineffective and Ageist Response to the Abuse of Older Adults, 16 FAM. L. Q. 69, 87 (1982) ("The push for mandatory reporting therefore would appear to be a reflection of the attitude that old persons, like children, need more assistance and guidance, whether or not they know it or even want it."); Mia M. McFarlane, Comment, Mandatory Reporting of Domestic Violence: An Inappropriate Response for New York Health Care Professionals, 17 BufF. PUB. INT. L. J. 1, 20-22 (1998) (identifying reasons why many oppose domestic-violence, mandatory-reporting laws); Gary B. Melton, Mandated Reporting: A Policy Without Reason, 29 Child Abuse \& NEGLECT 9, 14 (2005) ("It is plausible, for example, that health professionals' involvement in mandated reporting compromises their own or their clients' perception of them as helpers."). As a recent article points out,

$[\mathrm{M}]$ andatory reporting has the potential to deter victims from reporting their assaults to campus administrators and accessing the institutional resources that they are afforded under Title IX. Furthermore, attempts to force uninterested or unwilling victims to collaborate with law enforcement or prosecutors may negatively affect any collaborations that have been built between criminal justice system actors and campus/community advocates at the local level. In addition, mandatory reporting is not congruent with SaVE Act provisions mandating that IHE's inform student victims of gender-based violence regarding their right to report or to decline to report to law enforcement.

Tara N. Richards \& Katherine Kafonek, Reviewing State Legislative Agendas Regarding Sexual Assault in Higher Education: Proliferation of Best Practices and Points of Caution, 11 FEMINIST CRIMINOLOGY 91, 122 (2016).

87. Bolger, supra note 78; see also Rachel Coyne, Editorial, Dear Dr. Boorse, THE REVIEW (Oct. 13, 2015), http://udreview.com/editorial-dear-dr-boorse/ (voicing concern about faculty reactions to new policy).

88. I have several years of second-hand, anecdotal evidence about the statements of Delaware police and prosecutors to my students about their reluctance to pursue cases that involve alcohol. I have not, however, conducted a systematic study and I expect there is a great deal of variation. Others have conducted systematic studies and found a general and persistent bias against certain types of women and certain types of conduct. See Rose CORRIGAN, UP AGAINST A WALL: RAPE REFORM AND THE FAILURE OF SUCCESS passim (2013) (discussing continued reluctance to pursue rape convictions and assist all victims, regardless of who the person is); Frohmann, supra note 30, at 


\section{Campus Policy Reforms and Petty Bureaucrats}

A number of policies were under review and in the process of being updated by administrators during the period prior to the campus demonstration. Since the federal guidance regarding Title IX compliance, ${ }^{89}$ followed by passage of the Campus SaVE Act as included in the 2013 reauthorization of the Violence Against Women Act, ${ }^{90}$ the UD campus has made efforts to bring itself into alignment with its interpretation of new federal mandates. ${ }^{91}$ UD was particularly motivated since a student brought suit against the university for mishandling her complaint, ${ }^{92}$ and UD was subsequently added to the list of universities under U.S. Department of Education ("DOE") investigation. ${ }^{93}$ Thus we cannot separate the impact of the public demonstration in September 2014 from the threat of DOE intervention in terms of motivation for changing policy. Regardless of why the university felt compelled to change its policies, it is how those policies were changed and the discourse surrounding it that is of most interest to this Article.

In this section I discuss what I conceive of as mid-range policy change; that is, changes by the administrative units that address sexual assault, including the purely staff-run administrative efforts as well as efforts that required faculty assent, in order to bring their own policies in line with emerging standards. ${ }^{94}$ This section relies on data from public statements by

552-54 (finding that prosecutors reject rape cases based on victim characteristics such as race and socioeconomic status).

89. See Dear Colleague, supra note 49 (promulgating new guidance to help schools meet their obligations under Title IX).

90. See Violence Against Women Reauthorization Act of 2013, Pub. L. No. 113-4, § 304, 127 Stat. 54, 89-92 (2013). The 2013 Reauthorization Act gives the terms dating violence, domestic violence, and stalking the definition used for each in section 40002(a) of the Violence Against Women Act of 1994. Id. $\S 304(\mathrm{a})(3)(\mathrm{A})(\mathrm{i}), 127$ Stat. at 89.

91. See University Refocuses, supra note 10.

92. Delaware Sued for Mishandling Athlete Rape Allegation, INSIDE HIGHER ED (Jan. 3, 2014), https://www.insidehighered.com/quicktakes/2014/01/03/delaware-sued-mishandling-athlete-rapeallegation.

93. University Refocuses, supra note 10.

94. This description is something of a simplification. For example, responses to campus sexual violence are handled by a variety of agencies within the university, including residence halls, police, student health, and others. Ongoing efforts to coordinate these responses have been in place by a collaborative advisory group of staff and faculty, which has included representatives from the victim support hotline and others with direct service contact with survivors. It is important to note that many of the less obvious or less publicly debated reforms that have been made over previous decades have been a result of the work of these dedicated people and their predecessors. That this Article focuses on the more public, and thus hotly debated, changes is not meant to diminish the important and impactful work that has taken place behind the scenes. Rather, my focus on largescale and publicly debated change is used to illuminate the underlying beliefs and mechanisms at 
UD's Title IX Coordinator, who heads those administrative efforts, as well as by the university's General Counsel, who spearheaded changes to the standard of proof in finding faculty responsible for sexual misconduct, both of whom are categorized here using Weber's petty bureaucrats. ${ }^{95}$ The richest source of data comes from faculty senate proceedings and other public forums on these changes, which give us insight into how they were understood, or misunderstood, by faculty, staff, and students. Finally, I will discuss implementation, specifically how the Title IX Coordinator has interpreted staff and faculty obligations to report sexual violence.

\section{a. Reform as Improved Information: Low Expectations}

Underway since long before the protest, improving how the university explains Title IX and the related resources comprises the first visible reform to sexual assault response on campus. As the Coordinator explained, approximately one year after the protest and the tumultuous year of sustained campus concern, UD "put together a comprehensive sexual misconduct policy that applies to all faculty, students and staff with information that is all in one location, making it a little easier to find resources and information and give the help and information that people may need." ${ }^{96}$ Transparency is undoubtedly an improvement, and in fact helps remedy one of the pitfalls of bureaucracy. Making information clear and accessible can help to combat the bureaucratic compartmentalization and diffusion of responsibility that overwhelms both the users and the staff of the organization. But a related comment from a member of UD's staff underscores why providing better information as the crucial change borders on absurd:

I just wanted to make a comment about, a positive comment, about that small brochure, the spiral bound brochure that came out. I thought it was well done. I read it all the way through, and it actually taught me a few things. And I was like, wow, you know, there's some serious, carefully worded stuff. And what really made me feel good about it was I said, you know, I'm going to leave this on my desk. And I have seen it out on other people's desks. So it's a great document. And it helps build the culture, because we're talking about what happens when

work.

95. MAX WeBER, Bureaucracy, in From MAX WeBer: EsSAYS IN SOCIOLOGY 211, 225 (H.H. Gerth \& C. Wright Mills eds. \& trans., New York: Oxford, 1970).

96. Matt Butler, Title IX Coordinator Responds to AAUP's Policy Flak, THE REVIEW (Oct. 6, 2015), http://udreview.com/title-ix-coordinator-responds-to-aaups-policy-flak/ [hereinafter Coordinator Responds]. 
there's an incident. We're talking about after the incident, but what I think that document does is it takes another step forward to stopping the incidents from even happening.

This enthusiastic and well-meant support for the consolidation of information into one easily accessible brochure illustrates how low a bar of improvement we have set. The lack of attention to underlying causes is apparent here, and is magnified when campus leaders indicate their enthusiasm for improved communication about Title IX, while simultaneously spouting victim-blaming rhetoric. For example, at a November 13, 2014, meeting of mid-level administrators, the Title IX Coordinator presented a brief overview of policy changes. ${ }^{98}$ The agenda moved on, but with the Title IX slides still on the screen behind him, the Provost addressed the group about his first year on campus. When asked which key problems he had identified so far, he first mentioned the budget and then proceeded to describe all he had learned by walking around campus and listening to student conversations. Of particular note, he said, was the content of female undergraduates' conversations, which centered on boys and alcohol. He concluded by stating that we have a great deal to work on and that, "These are not Smith girls," unfavorably contrasting our ostensibly dumb and superficial co-eds with those at his previous institution.

\section{b. Reform Through Adoption of Preferred Terms and Elision of Gender as Analytic}

In part due to the DOE's various requirements, ${ }^{99}$ the university Title IX bureaucracy has consolidated information both in print and online. This included removing the designation gender-based violence in favor of the umbrella term sexual misconduct. This change in nomenclature required its own round of debate from faculty ${ }^{100}$ but ultimately came down to the

97. Open Hearing, supra note 3 (transcript at 21).

98. Notes from meeting on file with author, who attended the meeting as interim chair of the Women and Gender Studies Department.

99. See Violence Against Women Reauthorization Act of 2013, Pub. L. No. 113-4, § 304(a)(5), 127 Stat. 54, 89-91 (2013).

100. Some faculty were contentious in opposing the bureaucratic view that sexual misconduct could be equated with sex discrimination, while others were plainly just confused:

[Faculty name redacted] from Human Development and Family Studies. And pardon my question if it's just a stupid question. But if Title IX's really about sex discrimination, this policy is just about sexual misconduct. Why are we not . . I I mean, is it just that we'll come up with a different kind of a new rule around discrimination, gender discrimination, that's going to have a different set of standards for proof? So basically, like if you feel like you've been discriminated against on the basis of your gender, but 
bureaucracy's insistence that we must use the terms we are told to use. ${ }^{101}$

The shift to sexual misconduct and its use in a variety of policies obscures differences between sexual harassment and sexual assault and raises other concerns, as will be evident in quotes from confused faculty provided below. At a deeper level, removing gender speaks volumes. The advisory group, which shaped much of the campus's prevention and other efforts behind the scenes for many years, has traditionally emphasized the role of gender in sexual violence. Removing this attention undermines the necessary work of unpacking the notions of appropriate masculine and feminine behavior, which provide the scaffolding for sexual violence. ${ }^{102}$

\section{c. Reform as New Bureaucracy and Increased Reporting}

Campus leaders ${ }^{, 103}$ comments on changes since the September 2014 protest center on enthusiasm for the re-organization of UD's Title IX office:

We also have a committee structure set up by Sue Groff, as Title IX Coordinator, which is constituted of an executive committee that oversees all things related to Title IX. There's a case advisory board to review the cases, week by week, as they come in. There's a committee on tactics and resources, one on policy and communications, one on athletics, one on education and training for faculty and staff, and one on education and training for students. There is also, as a result of recent Senate action, a commission being assembled to work in coordination with all of these committees. In other words, we're doing a lot; this is a campus that's taking this seriously.

sexual misconduct wasn't included, would you still just need the overwhelming evidence, or would you be held to the higher evidence, overwhelming, or is this just the preponderance? I mean, I think that this is getting . . ., at least I'm confused.

Faculty Senate Open Hearing on the Revised Termination and Complaint Procedures of the Faculty Welfare and Privileges Committee, UNIVERSITY OF DElaWARE (Dec. 1, 2014) https://udcapture.udel.edu/podcast/watch.php?c=572 [hereinafter December Meeting] (transcript at 24, http://facsen.udel.edu/Sites/agenda/2014UDelSenatemeeting12-01-14.pdf).

101. General Counsel, Open Hearing, supra note 3 (transcript at 18); see also author's field notes (Nov. 13, 2014).

102. See Sharon Marcus, Fighting Bodies, Fighting Words: A Theory and Politics of Rape Prevention, in Feminists Theorize the Political 385-403 (Judith Butler \& Joan Wallach Scott eds., 1992).

103. It should be clarified that in Fall 2015 an interim president took over, but while the top leadership changed near the end of the period of this study, the relevant provosts remained the same.

104. Vice Provost, Open Hearing, supra note 3 (transcript at 11); see also University Refocuses, supra note 10 ("University President Patrick Harker also released a letter to the university community emphasizing that the university is 'vigilant' when it comes to the safety of its students, faculty and staff. 'Gender-based crimes - sexual assault, sexual harassment, intimate partner violence and stalking — are serious, and they're taken seriously at UD.'”). 
Accounts of progress also focus on the broad increase in reports of sexual harassment and assault. ${ }^{105}$ These commonly take the form of comments like,

Even though we're on the list, I think it needs to be known that people here are doing the right thing and we're all well-intentioned .... The process is a little disiointed and I think that's what got us in trouble, but as far as what we're doing. I know we're doing the right thing and it's really just about pulling it together and cleaning up that process a bit. ${ }^{106}$

The bureaucratic responses to calls for action and improvement reflect a very low level of expectation for demonstrating change. As a member of the faculty noted during a debate about changing the standard of proof, focusing on what the federal government may require rather than on the substance misses the larger ethical point:

But I think even considering taking on the feds on this is kind of losing sight of what I think is the really most important issue, and that is that, as an institution I think we failed. I was a little surprised to hear [Vice Provost] say we have a good story to tell, because I don't think we do at this point have a very good story to tell.

In addition, although campus leaders and bureaucrats have enthusiastically described the increase in reports, no effort has been made to disaggregate the reports by type. ${ }^{108}$

This requires skepticism for at least two reasons. First, empirical research on patterns of reporting show increases during periods of audit followed by a return to prior levels once administrative attention is less urgent. ${ }^{109}$ Second, the increase in the umbrella category of total reports likely includes a larger number of more minor cases or allegations related to harassment, workplace discrimination, or events that took place in the distant past that are being reported because of an overly expansive interpretation of mandated reporting. ${ }^{110}$ In fact, other measures indicate that far fewer students are disclosing sexual assault to those to whom they have

105. See Offredo, supra note 75 ("Campus officials say an increased dialogue and stricter reporting guidelines has led to an increase in sexual assaults reported to UD police last year. In 2013 three cases were reported, compared to eight last year. But there are still concerns that the numbers reported are low and not an accurate picture of incidents. Many victims do not report attacks.").

106. University Refocuses, supra note 10 (quoting UD Title IX coordinator, Susan Groff).

107. Member of the Faculty, Open Hearing, supra note 3 (transcript at 24-25).

108. Department informational meeting with Title IX Coordinator, December 10, 2014 (notes on file with author).

109. Corey Rayburn Yung, Concealing Campus Sexual Assault: An Empirical Examination, 21 PSYCHOL. PUB. POL'Y \& L. 1, 6 (2015).

110. See infra Part III.A.3. 
in the past. ${ }^{111}$

\section{d. Changing the Burden of Proof for Faculty Sexual Misconduct: Miscognition and Myth Accommodation}

The first hotly contested policy reform advanced in the wake of campus attention centered on the standard of proof used in faculty disciplinary proceedings. Unlike the policies around student conduct, which were not subject to debate, the Faculty Senate had to approve the shift from a finding of responsibility based on clear and convincing evidence to a finding based on preponderance of the evidence, the standard declared by the $2011 \mathrm{DOE}$ Dear Colleague letter. ${ }^{12}$

The change could not be agreed upon in the November 2014 faculty senate session and thus was carried over. ${ }^{113}$ Concerns ranged from utter confusion over the terms, as discussed above, to the erosion of faculty power and threats to faculty independence, framed through due process and faculty governance: ${ }^{114}$

I see this lower standard as a complete violation of those rights. And it is due process that protects both complainants and perpetrators in these cases, and I feel like we were are going down a terrible road. I hear

111. During a Faculty Senate Commission session on March 12, 2015, faculty in the Women and Gender Studies Department shared that there was a precipitous drop in the number of students seeking support for sexual assault. Notes on file with author. While most faculty in that department usually field a number of requests for support each semester, in the months following the university's announcement of mandated reporting only one student came forward to a member of the department. See Coordinator Responds, supra note 96 ("The main argument against mandatory reporting posed by the AAUP is its interference in the normal student-faculty relationship, since it could potentially stop a student from reporting a sexual crime to a professor if that professor was then required to report it to someone else. 'Having to inform students that we are required to report instances of sexual misconduct to the administration will make it less likely that students will disclose such instances to us,' the [AAUP] newsletter said. 'It is a counterproductive intrusion into relations among students and faculty."').

112. See Dear Colleague, supra note 49, at 10-11 (asserting that a preponderance of the evidence standard should be used because the Supreme Court applies the same in Title VII litigation).

113. Official Minutes of the Univ. OF Del. Faculty Senate 9 (Dec. 1, 2014), http://facsen.udel.edu/Sites/minutes/FACSENminutes2014December.pdf.

114. The debate about the rights of the accused and the rush to accommodate victims at a cost to common sense and other values such as intellectual freedom has been well documented elsewhere, including in this Symposium Issue of the Kansas Law Review. See Gruber, supra note 59, passim; Lave, supra note 70 at 955 (commenting that a preponderance of the evidence standard is "too low for what is at stake for the accused student"). See, e.g., Wendy Kaminer, The SaVE Act: Trading Liberty for Security on Campus, THE ATLANTIC (Apr. 25, 2011), http://www.theatlantic.com/national/archive/2011/04/the-save-act-tradingliberty-for-security-oncampus/237833 (asserting that the SaVE Act goes too far in attacking freedoms). 
you, [redacted], about why the university is reluctant to do anything other than this, but I think it's a very dangerous place to be and it makes me very uncomfortable.

In both sessions, the change in the standard of evidence to procedures for sexual harassment allegations against faculty were presented by the university's General Counsel as a clear and unequivocal mandate from the DOE. ${ }^{116}$ When faculty raised concerns, either confrontationally or with more awareness of the divide between lofty lawyers and lowly professors, Counsel insisted on the need to follow the accepted form. For example, a professor stated, "I do not agree with the lowering of standard of proof. I do not think, although I'm just a biologist, that it is founded in the law; I think it's founded in an interpretation of the law." "117 After several faculty members questioned the mandate's authority, Counsel responded, "So you are right, and if we had a semester to talk about the Administrative Procedure Act, I would explain the difference between a regulation and a good guidance practice."118 After further back and forth between Counsel and several faculty, Counsel closed the debate with the kind of dismissal that characterizes Bourdieu's miscognition, demonstrating the privilege of having the more relevant and practical knowledge that belongs to lawyers:

FACULTY, PHILOSOPHY: It's just troubling when the fundamental terms of this document are quite unclear. And you might say that you're inheriting unclarity from the relevant federal statutes or interpretations, but it's still troubling if we're not to know exactly what falls into the relevant categories. This document gives us some examples that might count, but, I mean, what does that tell you? They might count?

COUNSEL: This may be one of the wonderful examples of a lawyer and a philosopher talking over each other. This is a definition that is designed to be, first of all, satisfactory to [DOE Office for Civil Rights ("OCR")], and second of all, to comprehend within it, all forms of sexual conduct that are outlawed by Title IX.

This exchange also exhibits the use of an accepted form. In this case, the

115. Member of the Faculty, Open Hearing, supra note 3 (transcript at 25-26).

116. General Counsel, Open Hearing, supra note 3 (transcript at 14); General Counsel, December Meeting, supra note 100 (transcript at 12-14); see also Standard of Proof, supra note 12 (reporting on meeting where Counsel explained new standard of proof).

117. Member of the Faculty, December Meeting, supra note 100 (transcript at 15).

118. General Counsel, Open Hearing, supra note 3 (transcript at 17).

119. Open Hearing, supra note 3 (transcript at 30-31). See also Bourdieu, supra note 33, at 817-18 (discussing miscognition). 
form used is an officially sanctioned definition of prohibited conduct, portrayed as the bottom line: we must use the definition other institutions have used in order to appear compliant. This is particularly noteworthy given that DOE lacks enforcement powers, ${ }^{120}$ although it can refer matters to the Department of Justice for injunctive relief in federal court and suspend or terminate federal funding. ${ }^{121}$ Nonetheless, university leaders and petty bureaucrats insist that the federal changes are both clear-cut and mandatory. Rather than by established rules or case law, UD's bureaucratic reforms have been guided by fear of what might be included in a conciliation agreement looming on the horizon in response to the aforementioned DOE investigation that is still pending at the time of this writing. As General Counsel explained in response to the quibble over terminology, "OCR has taken the position in negotiating conciliation agreements that all policies that are covered by Title IX, all sexual harassment policies are covered by these 'Dear Colleague' letter rules.", 122

120. See Clery Act $\S 204,20$ U.S.C. § 1092(f)(2) (2012) (stating that DOE cannot require schools to adopt particular policies and procedures).

121. See Civil Rights Division, U.S. Dep'T of Justice, Title IX Legal Manual § VII (last updated Aug. 6, 2015), http://www.justice.gov/crt/title-ix (click on desired section to jump to content) (clarifying that Title IX guidelines are based on those of Title VI, 28 C.F.R. § 50.3 (2011), and its subsequent clarification in case law and explaining that it would be up to the other federal agencies that would otherwise be awarding funding, for example the Department of Justice's sponsorship of research, to refuse to fund the research because of an OCR finding of noncompliance).

122. General Counsel, Open Hearing, supra note 3 (transcript at 27). Counsel further clarified the threat of enforcement:

And I also, if I could, should talk about the Tufts situation. Tufts, in the spring of 2014, took the position that you're espousing. And they said to [DOE], we're not going to sign your voluntary conciliation agreement, we don't think you have the authority to require us to do some of the things you're requiring us to do in that agreement. Forty-eight hours later [DOE] announced its intention to institute proceedings to debar Tufts. They're serious in their enforcement strategies in this area. If we were to insist on our right to have a clear and convincing evidence standard, we'd be the subject of an enforcement proceeding.

$I d$. at 23. One of the most interesting moments in either session took place when Counsel slipped out of his role as confident proponent of a single clear mandate and acknowledged the ambiguity:

What we're trying to do is to prepare for a visit by [DOE] in the spring, by putting together as strong a portfolio of policies as we can we can [sic], with the benefit of three and a half years of insight into what will trigger [DOE] scrutiny. And that's as good as I can do. This is a nightmare for you and for us and for everyone else. In my 35 years of being a higher education lawyer, I have never seen an area of jurisprudence move so far so fast, as this one. And there are tremendous inconsistencies in the law, inconsistencies between our treatment of sexual assault and our treatment of other vices. But we have the practical problem of trying to position this university as strongly as we can, because we're one of 85 universities that are being investigated by [DOE] at this point. So we're doing the best we can

General Counsel, December Meeting, supra note 100 (transcript at 30-31). Counsel later added, 
In addition to pressures towards isomorphism (i.e., making UD's policy look just like what we think our peer institutions' policies look like), ${ }^{123}$ some of the rhetorical strategies used to resist Counsel's interpretation resorted to criticism of whether any problem actually existed:

Part of the reason I think for this confusion, at any rate my own, is that, when you talk about sexual violence, I don't think you're talking about something that waited for Title IX to become illegal. I mean, doesn't that mean rape? And that is such a, I mean, it's a capital offense, back in the days of yore, even if often not enforced. And so why is that part, why can that capital offense be under a lower standard of proof, because Title IX wishes to keep people from being discriminated against, because all women have to be secretaries or something. ${ }^{124}$

Lurking beneath this objection to a lowered standard of proof, or to the "special treatment" of sexual harassment (which happens to be a concern I share and that I expressed via written statement read to the Senate), is an unsettling repetition of outdated notions about the need for law to protect against discrimination. Such repetition is evident here:

I agree with the concerns raised against how broad "sexual misconduct" is. And to just take this conversation one step further, let's say that I feel that women in STEM fields are under-represented, right? So I actively pick a woman graduate student over a male graduate student because I think there ought to be more women in STEM fields. That's clear-cut sexual discrimination and under this rule it would be included and I would be terminated. Now, I mean, if we don't mean that to be the case we ought to change it to exclude that sort of type of a thing.

While one might be tempted to dismiss this as simply hopeless ignorance, it presents an extreme example of a more subtle but widespread current running through objections to policy change: objections rooted in dismissal of sexual harassment itself. ${ }^{126}$ Other comments also alluded to the belief in real evidence, implying that cases are often unfounded or at least un-

\footnotetext{
"I'm speaking only as a lawyer, I'm not speaking in terms of what ought to be right, what we ought to be doing." Id.

123. See Rubin, supra note 41 , at 373-75 (positing that "[c]onformity with . . . norms or expectations conveys legitimacy" and describing the types of pressure that bear on organizations to conform).

124. Member of the Faculty, December Meeting, supra note 100 (transcript at 29).

125. Member of the Faculty, Open Hearing, supra note 3 (transcript at 31 ).

126. As both a feminist and a supporter of due process, and therefore in opposition to Counsel's proposed changes, I found this current particularly noteworthy since it left me wondering whether such bedfellows were worth their support.
} 
provable, as in this quote from a long-time member of the disciplinary board that oversees faculty misconduct: "And very few sexual harassment cases get to the committee. They are dealt with before that point is reached. And usually the, if it's, there's real evidence, the faculty member resigns and is gone. I don't think I ever saw a case get to the committee."127

This comment is particularly troubling when reinforced by members of the university administration:

[Resistance to policy change stems from fears] that there's a leveling out here, that there is a sort of effect as a result of the expansion of Title IX of weakening our policies or lowering our standards or treating anything that falls under sexual misconduct as an offense of the same magnitude.

While not necessarily espousing the view himself, the university administrator here articulated belief in a "harm continuum," 129 which contributes to the undervaluation of victimization and the potential for dismissing conduct that does not rise to a threshold of real evidence, harm, or misconduct, or that is not of the same magnitude. Such undercurrents in the protest to campus reform demonstrate the kind of myth accommodation also exhibited by the Delaware legislators ${ }^{130}$ and campus leadership. ${ }^{131}$ Myth accommodation, as evident in this case study, means the use of rhetorical strategies that minimize the existence or significance of sexual misconduct itself as a way to prevent threats to the status quo.

Ultimately, the bureaucratic insistence on preempting what might happen by adopting reforms, what I call legal endogeneity in anticipation, won the day, since the fear of possibly losing money - or of appearing to accommodate rape myths - swayed the majority of faculty senate votes.

\section{Not Just Talk: Reform as Mandated Reporting by Faculty}

Up until this point, the case study has focused on policy reform and the debate surrounding it. It would be extremely worthwhile to evaluate implementation of these reforms, including testing whether the new, clearer language about the policies' content and how to use them, as well as shifts in the structure of the office, have indeed facilitated victim utilization. But the

127. Member of the Faculty, Open Hearing, supra note 3 (transcript at 39).

128. Vice Provost for Faculty Affairs, Open Hearing, supra note 3 (transcript at 8).

129. See LEON, supra note 17, at 62-64.

130. See supra Part III.A.1.

131. See supra Part III.A.2.a ("These are not Smith girls."). 
changes are too recent even if it were possible to access a representative sample of users and potential users, which is something that could not happen without institutional support, the careful negotiation of confidentiality, and other protections. In the meantime, we can examine one concrete interpretation of policy: the promulgation and implementation of new requirements that tell faculty to report any and all instances of possible sexual violence to the Title IX office with identifying information. ${ }^{132}$

The Title IX Coordinator began her tenure with a series of informational sessions directed to faculty, staff, and students, including public presentations as well as visits to department meetings and other gatherings of faculty. I attended four such sessions over a period of four months. ${ }^{133}$ During this time, the Coordinator presented some of the reforms described above (new umbrella language and changes in user-interfaces), but drew the most confusion and follow-up questioning when she presented her office's interpretation of the faculty duty to report possible Title IX violations to her office. $^{134}$

The confusion and eventual conflict over this policy stems from different understandings of the underlying problem. The Coordinator stated her conception of the problem during the first month of her first semester in the role:

In the first week of the school year, the university's Title IX Coordinator Susan Groff received 13 Title IX reports, four of which were alleged rape cases that occurred mostly during move-in weekend. "That is what was reported to my office," she said. "Unfortunately, I would speculate that there were more incidents that occurred that were not reported." 135

As did the Delaware state legislators, ${ }^{136}$ the Coordinator located the problem

132. Hereinafter "mandatory reporting," which must be distinguished from the kind of mandated reporting to police discussed above.

133. University of Delaware Title IX Coordinator Informational Sessions (Sept.-Dec. 2014) (notes on file with author).

134. Meghan Jusczak, Second of Title IX Info Sessions Poorly Attended, Raises Questions About Mandatory Reporting, THE REVIEW (Oct. 22, 2014), http://udreview.com/second-of-title-ix-infosessions-poorly-attended-raises-questions-about-mandatory-reporting/; see Office of Equity \& Inclusion, Univ. of Del., Title IX Information Briefing Transcript 3, http://www.udel.edu/oei/knowledge-awareness/titleIXtranscript.pdf (describing the mandatory reporting policy).

135. University Refocuses, supra note 10.

136. See Bolger, supra note 78 (explaining a bill that Delaware legislators tried to push forward that would allow rape reports to be submitted to the police without victim consent and stating that this would lead to fewer survivor reports). 
as victim non-participation in the process, which may come across as essentially another shade of victim blaming. ${ }^{137}$ Rather than stopping rapists from raping, or otherwise promoting prevention, the Coordinator built on her statement above about likely under-reporting by rolling out a policy that removed control from victims. ${ }^{138}$ In contrast, experts in trauma-informed care explain that victims benefit most from interventions that recognize their agency ${ }^{139}$ and that understand their often well-grounded concerns about revictimization and other risks associated with lodging formal reports. ${ }^{140}$ As discussed above, addressing victims as if they are themselves the problem not only raises ethical and moral concerns, but also has been empirically demonstrated to undermine systems that work to end sexual violence, including the criminal justice system. ${ }^{141}$

Nonetheless, the Title IX bureaucratic structure targets improved reporting. In order to anticipate possible censure during the then-pending DOE investigation, UD's Title IX Coordinator argued that any and every scrap of information about past sexual abuse, however far removed from the campus in time or geography, must be reported to her office, with information that identified the alleged victim so that the Coordinator's office could follow up. ${ }^{142}$ When faculty described fears of how this would chill their ability to maintain rapport with help-seeking students, the Coordinator's office responded by modeling ways that faculty could stop conversations that might lead to disclosure mid-stream and explain that

137. See Burt, supra note 32, at 134-35 (discussing rape myths arising from the notion that "she deserved it").

138. See Office of Equity \& Inclusion, supra note 134, at 3 ("[Y] ou cannot offer confidentiality, and you have to report any disclosure of sexual assault or sexual harassment to The Title IX Coordinator or one of the other Deputy Coordinators."). See generally Debra Patterson et al., Understanding Rape Survivors' Decisions Not to Seek Help from Formal Social Systems, 34 HEALTH \& SOC. WORK 127 (2009) (discussing victims' reticence to report to formal social systems).

139. Megan R. Greeson \& Rebecca Campbell, Rape Survivors' Agency Within the Legal and Medical Systems, 35 PSYCHOL. OF WOMEN Q. 582, 592-93 (2011).

140. Id.; see Megan R. Greeson et al., Cold or Caring? Adolescent Sexual Assault Victims' Perceptions of Their Interactions with the Police, 29 VIOLENCE \& Victims 636, 646-50 (2014) (recommending best practices for police when working with adolescent, sexual-assault victims); see also Bumiller, supra note 44, at 425-26 (noting victims' reasons for not reporting discrimination).

141. See supra notes 84-86 and accompanying text. It is worth noting that during the few instances when the UD Chief of Police has made public statements, he reflects a more nuanced understanding of working with sexual assault victims. See University Refocuses, supra note 10 ("He said students often choose to go through the university process rather than the criminal proceedings because it is less formal and allows for confidential reporting.").

142. University of Delaware Title IX Coordinator Informational Sessions (Sept.-Dec. 2014) (notes on file with author); see also Office of Equity \& Inclusion, supra note 134, at 5 ("The law is clear that the University has notice of an incident when a responsible employee knows .... So it's very important that if you know of an incident, that you report it so we can begin the processes ...."). 
anything that followed might have to be reported. ${ }^{143}$

\section{B. Changing the Process Without Changing the Experience?}

The September 2014 campus demonstration and subsequent attention from faculty, staff, and students to the prevalence of sexual violence and the gaps and the organization's response to it, constituted an opportunity for university leaders, as well as the Title IX bureaucracy, to cohere around a new message of inclusion and support. Instead, the response has been ragged: implemented with resistance from faculty, while exhibiting outdated notions of what sexual misconduct means, and appearing to prioritize compliance and the shoring up of bean-counting over the core concerns of ending sexual violence and treating victims with care. ${ }^{144}$ Without university leadership offering explicit statements of concern or concrete plans for support, ${ }^{145}$ factions have festered and the opportunity to come together appears to have been wasted. ${ }^{146}$ That said, policies and their implementation take time to show results, so we can hope to see measurable impact on the incidence of sexual misconduct as well as in participants' satisfaction with the process in the future. But there is a long way to go.

Without a sense of shared endeavor, and instead marred by distrust, we cannot expect members of the university community to take advantage of the resources offered by the Title IX bureaucracy. This became clear at a forum held about six months after the campus protest:

Halfway through Monday's open forum on sexual assault and harassment, political science professor Stuart Kaufman asked for a show of hands." A few minutes ago, [a student] made a very strong statement," Kaufman said. "He said, 'I don't trust the administration.' [...] How many people are willing to associate themselves with that?"

143. University of Delaware Title IX Coordinator Informational Sessions (Sept.-Dec. 2014) (notes on file with author).

144. For documentation of similar failures to take advantage of opportunities for change, see Corey Rayburn Yung, Is Relying on Title IX a Mistake?, 64 U. KAN. L. REV. 891, 899-902, (2016).

145. The University President did release a letter stating that the university is "vigilant" regarding safety. University Refocuses, supra note 10. Several days later, however, a provost issued an open letter again highlighting safety but indicating that university policies are appropriate and sufficient. Open Letter from University of Delaware Provost Domenico Grasso (Sept. 18, 2014), https://sites.udel.edu/provost/files/2015/01/Open-Letter-to-the-University-Community-1wjdakt.pdf.

146. See Sage Carson, Opinion, Student Attendance at Title IX Meetings "Scrawny", THE REVIEW (Nov. 3, 2014), http://udreview.com/opinion-low-student-attendance-at-title-ix-meetingsscrawny/ (discussing students' need to continue participating in the process, and detailing their failure to do so at the time). 
Three-quarters of the people in attendance raised their hands. ${ }^{147}$

While this informal poll no doubt reflects a sample skewed towards those concerned enough about Title IX to attend the hearing, it remains a meaningful symbol. As described in an article about the session,

One such student, freshman Harry Lewis, initially brought up the issue many had with the administration. He cited the administration's response to the alleged sexual harassment of a student by [a] former professor [redacted] and its subsequent response when those allegations were made public by The Review as an example.

"It wasn't just about the incident but about the language used surrounding it," Lewis said. "And when [the university community] found out about it, we were told to shut up, it'll go away. My question is, why should we trust [the commission]? Because everyone in the administration, they're not obliged to take these recommendations to heart." 148

This student gets to the core of my argument. While research investigating citizens' interactions with police indicates that procedures can satisfy participants even when outcomes are not what they expect, ${ }^{149}$ research on legal endogeneity has not to this point been connected with outcomes or with substantive experiences of those involved. This case study of Title IX implementation in the wake of protest indicates that forms and procedures must be accompanied by more: we must have evidence that they are taken to heart.

\section{CONCLUSION: TAKING IT TO HEART}

\section{A. Beyond the Petty Bureaucrats}

What more should be done? Is it fair to criticize the Title IX bureaucracy for problems that are likely beyond its scope? Perhaps not, but it would be easier to have patience with this bureaucracy if it evidenced attention to underlying core concerns or if it listened to stakeholders. For

147. Meghan Jusczak, Distrust of Admin. Evident at Sexual Assault Forum, The ReviEw (Mar. 9, 2015) http://udreview.com/distrust-of-admin-evident-at-sexual-assault-forum/ [hereinafter Distrust].

148. Id.

149. Tom R. Tyler, What is Procedural Justice?: Criteria Used by Citizens to Assess the Fairness of Legal Procedures, 22 L. \& SOC'Y REV. 103, 128 (1988); see also Lave, supra note 70 at 952-953. 
example, rather than facilitate shared conversations or other campus events that might draw attention to our own myths or other barriers to prevention, the Title IX bureaucracy has mandated online training for all students at UD and attempted to require it for faculty and staff as well. ${ }^{150}$ In an unfortunate and poorly managed conflict with the faculty labor union, the bureaucracy backed off and the training is not required. ${ }^{151}$ On the one hand, arguing over sexual misconduct makes the faculty look tone-deaf, in keeping with the kinds of oblivious statements described above. But the content of the training was not only superficial; it focused on compliance ${ }^{152}$ while the content perpetuated myths about who victims and perpetrators are. ${ }^{153}$

There is evidence that this may be changing, stemming from UD's top leadership who eventually fully staffed and resourced the Title IX bureaucracies. Much of the Title IX Coordinator's response in the period under study has been reactionary, both to the federal government and the campus protest and its accompanying sustained attention from the campus newspaper and faculty senate commission. Throughout her short tenure, the Coordinator has decried the inadequate budget allocated to her office and has repeatedly described how short-staffed the office is. ${ }^{154}$ In a forum with

150. See Office of Equity \& Inclusion, supra note 134, at 1-2 (stating that among the Title IX Coordinator's responsibilities is to ensure that education and training for both employees and students occurs); Violence Against Women Reauthorization Act of 2013, Pub. L. No. 113-4, § 304(a)(5), 127 Stat. 54, 89-91 (2013) (stating that VAWA tells campuses to provide clear sexual violence policies and to train all incoming students and new employees).

151. Coordinator Responds, supra note 96.

152. See Alison Wilson, Title IX Investigators Look to Open Channels of Communication, THE REVIEW (Sept. 16, 2015), http://udreview.com/title-ix-investigators-look-to-open-channels-ofcommunication/ ("Online training requirements are mandatory for employees to assure they are aware of policies and guidelines.").

153. University of Delaware Title IX Compliance Training (notes on file with author). There is no clear federal requirement as to the content of training or other awareness efforts. See 20 U.S.C. § 1092(f)(8)(B) (2012) (stating required education, procedures, opportunities, and information rights without reference to any specific training processes). The training module used by UD seems to be fee-based and proprietary and not available to the public, but I engaged in the training and made notes on the way it featured stereotypical young white female victims in its text and imagery, as did a number of my peers. University of Delaware Title IX Compliance Training (notes on file with author). The fact that the training was lousy contributed to the Union's resistance to engage in it, as well as the loftier concern about faculty independence both of which are concerns I happen to share. Id.

154. Jagoda Dul et al., University Implements Revised Title IX Policy, Hires Investigators, THE REVIEW (July 26, 2015), http://udreview.com/university-implements-revised-title-ix-policy-hiresinvestigators/ ("Groff . . . felt 'overwhelmed' by her duties and responsibilities at an SGA meeting in March. Since a failed search for new hires last fall, Groff has been the only administrator solely focused on Title IX policies and investigations."); Meghan Jusczak, Title IX Coordinator: Office Is Short Staffed, THE REVIEW (Mar. 24, 2015), http://udreview.com/title-ix-coordinator-office-is-shortstaffed/ [hereinafter Short Staffed] (outlining the issues that being short staffed pose). This understaffing undermines the efficacy of the complaint process. For example, I helped a student 
student government, the Coordinator was asked about her goals for the Title IX office over the next five to ten years: "Susan Groff said she would likely be too 'burnt out' to stay in the position long enough to make those plans. 'Gone and out of here,' she said...." recognize, as it demonstrates that the lack of satisfactory action from this bureaucracy can be partially attributed to the priorities set by national and campus leadership. ${ }^{156}$ Criticism of petty bureaucracy need not focus on the person inhabiting the role, but on the structure that sets up that person for burnout - and for a misguided target. While campus leadership has gestured towards the existence of the Title IX Coordinator as in itself a sign of concern about sexual violence, this can be viewed as another shade of legal endogeneity: create an office and put someone in a role and we send a symbolic message of concern, ${ }^{157}$ no matter the resources, expertise, or discretion available to the office or its ability to actually implement policy change. However, nearly a year after the protest, the approach to responding to complaints shifted from a hearing model to an investigation model, ${ }^{158}$ and

submit a complaint that included significant fears for the student's safety on a Friday. But because the Coordinator was out of town at a DOE training conference, no one read the complaint until she returned to the office the following week, and we received no response to a complaint until midweek. The bureaucracy has since made it easier to submit complaints electronically, but at the time (January 2015) the numerous complaints produced by the bureaucracy's implementation of mandated reporting apparently sat on desks until the only person in the office able to read them was able to do so and to do triage. This also highlights the gap between the public declaration of improvement in making information about reporting accessible and the actual process of receiving and dealing with reports. A colleague shared a similar experience regarding the long wait for response that took place during this same time. Correspondence on file with author.

155. Short Staffed, supra note 154.

156. Here I respectfully disagree with my colleague, Professor Katharine K. Baker, who defends the federal government and specifically DOE as promoting needed change for ending sexual violence. Katharine K. Baker, 64 U. KAN. L. REV. 861 (2016). My concern is extrapolated from that evidenced in my case study: that by merely requiring specific forms, such as changes in the standard of proof or investigator models, without requiring active measurement of what compliance means, we are sacrificing substance for form.

157. Vice Provost for Faculty Affairs, Open Hearing, supra note 3 (transcript at 10) (including the university administrator's comment described above, "[w]e also have a committee structure ... this is a campus that's taking this seriously").

158. Cady Zuvich, Title IX Investigators to be Hired by July 1, THE REvIEw (May 12, 2015), http://udreview.com/title-ix-investigators-to-be-hired-by-july/ [hereinafter Investigators]. The shift away from the hearing model, while largely welcomed by victim advocates and the professionals who work with them, also introduces due process concerns, some of which have been raised by faculty. See Dul et al., supra note 154 ("Prominent student activist Sage Carson said the hirings are a positive step forward for the school's 'maligned' sexual misconduct response programs. She said the investigator system alleviates some of the intimidation that accompanies the former hearing panel system."). In the hearing model, the accused ("respondent") participated in a process associated with a formal adjudicative hearing, including the presentation of evidence and some form of written or verbal testimony from the complainant. See id. In my anecdotal experience working with two students who were accused, however, little due process was actually experienced and 
two new mid-level hires were added. ${ }^{159}$ At least at the level of rhetoric, these investigators welcome more of the kind of openness to the campus community $^{160}$ that would be helpful for defusing the hostility built up towards the bureaucracy so far. ${ }^{161}$ However, the best possible indication of a move towards a more welcoming and open climate for addressing sexual violence would come from UD's top leadership. As a deputy provost shared, "[t]here are also many people [in the administration] who understand there have been missteps and we're working now to rectify a lot of those missteps .... We want to get this right. It's really important to engage in this even if you feel frustrated." 162

It remains to be seen if the new president (incoming in July 2016) is willing to continue this line of dialogue, to put resources into sexual violence prevention and intervention, and to regularly measure outcomes, including participants' satisfaction with Title IX investigations as well as measures of attitudes and behaviors. ${ }^{163}$

certainly no sense of procedural justice was felt. See Lave, supra note 70 at 950-58 (presenting a thorough analysis of due process concerns in similar hearings). In the UD context, this has unfortunately been another issue over which faculty concerned about these due process issues have failed to frame their concerns in ways that evidence their overall support for responding appropriately to sexual violence, with a few exceptions.

159. Dul et al., supra note 154 .

160. See Wilson, supra note 152 ("Two new staff members were appointed this summer to assist Susan Groff, Title IX coordinator, in educating the community about matters of sexual misconduct and harassment. To do this, they said they want to collaborate with the student body. Senior Associate Director for the Office of Equity and Inclusion Fatimah Stone and Associate Director Michael Kelly were hired to do investigative work and provide support and outreach to the campus community. In their roles, they wish to create a welcoming environment where students feel comfortable to express themselves freely, just as the one-on-one guided process was put in place to make reporting incidents less intimidating. 'We are approachable,' Kelly said. 'We'd love for [the students] to come up and sit down and talk with us.' Stone emphasized this point also. She said the OEI wants to hear from the students how to best represent them and get information to them. Their goal is to be interactive with the community.").

161. See Distrust, supra note 147 (describing a faculty leader contrasting the method of his own commission with that of the Title IX bureaucracy, which he suggests has been too hierarchical in its interactions with students, "He thinks advertising the forum as an open discussion rather than as a presentation was beneficial, and better encouraged students engaged with the topic to come out").

162. Id. (alteration in the original).

163. These measures must go beyond one-time climate surveys. See Cady Zuvich, For Title IX Probe, Fed. Investigators to Interview Students Next Week, THE REVIEW (Apr. 28, 2015), http://udreview.com/office-of-civil-rights-to-visit-campus-next-week/ (describing the survey conducted at UD in response to a federal complaint against the university). In another strand of DOE guidance, universities have been encouraged to conduct climate surveys. U.S. DEP'T OF EDUC., Questions AND ANSWERs ON Title IX AND SEXuAl Violence 20, http://www2.ed.gov/about/offices/list/ocr/docs/qa-201404-title-ix.pdf (suggesting a climate survey as a way to limit the effects and prevent recurrence of sexual violence); WHITE HOUSE TASK FORCE to Protect Students from Sexual Assault, Not Alone: The First Report of the White HOUSE TASK FORCE 2, 7-8 (2014), https://www.notalone.gov/assets/report.pdf ("The first step in 
In another positive sign, the Delaware legislators who initially resisted input about the potential problems of mandatory reporting to off-campus law enforcement for victims of sexual assault on campus, have backed down. ${ }^{164}$ Their revised legislation emphasizes that victims have the option of nonUniversity reporting. ${ }^{165}$

\section{B. Beyond Compliance}

Scholars have pointed out that bureaucracies often fail us. In particular, we are learning more about why organizations fail to act responsibly, including the work of Hefner on child sexual abuse discussed above. ${ }^{166}$ Hefner explores why numerous actors failed to fulfill their duty under the law as mandated reporters. In work describing the artificial and short-term impact of DOE audits on campus sexual assault reporting, Yung argues for more frequent auditing and higher penalties for noncompliance. ${ }^{167}$ In contrast, my data shows that compliance may be the wrong problem. I would argue that rather than focusing on failure to comply with the "law," we should focus on moral and ethical failures to act as we should, as well as question why our law asks so little of us.

This case study shows that legal endogeneity is applicable beyond judicial deference, and in fact shows that university petty bureaucrats also reflect its influence. I thus argue that anticipating judicial or administrative conceptions of compliance is another impact of the subtle effect of legality outside of the courtroom.

Specifically, I find that legality, and more narrowly "compliance" with

solving a problem is to name it and know the extent of it - and a campus climate survey is the best way to do that."). Yet little to no assistance has been made available from the federal government in crafting these surveys or in using validated measures. Personal correspondence with two of the people tasked with administering UDs climate survey in spring 2015 (correspondence on file with author).

164. Matthew Albright, Bill Would Change Sexual Assault Process for Colleges, DEL. NEWS J. (March 3, 2016), http://www.delawareonline.com/story/news/education/2016/03/03/college-sexualassault-bill/81263668/.

165. Id. No public statement from the original sponsors explains their shift, but they may have been influenced by public pressure, such as the 300 plus signatories to a change.org petition. Sage Carson, Support Survivors: Do Not Proceed with House Bill 1, CHANGE.ORG, https://www.change.org/p/delaware-state-house-valerie-longhurst-kimberly-williams-karenpeterson-do-not-proceed-with-the-introduction-of-a-college-campus-sexual-assault-reportingbill?recruiter=287791905\&utm_source=share_petition\&utm_medium=facebook\&utm_campaign=au topublish\&utm_term=mob-xs-share_petition-reason_msg\&fb_ref=Default (last visited Mar. 19, 2016).

166. Hefner, supra note 28.

167. Yung, supra note 109 , at 1. 
Title IX, is inferred from the mere presence of structures. Faculty and administrators claim that we are doing well in addressing sexual violence if we have policies and procedures in place, leaving their response at that superficial level and not inquiring into how policies are carried out or fully investigating aspects of the ground level implementation. ${ }^{168}$

This connects with what scholars of punishment call actuarial justice, which is the idea that if we can count something we have shown that we are doing our job. ${ }^{169}$ For example, if we can count increased sexual assault reports to the Title IX office, we can call that in itself improvement. Figure 1 depicts the relationship between low expectations and symbolic compliance that illustrate legal endogeneity as suggested by this case:

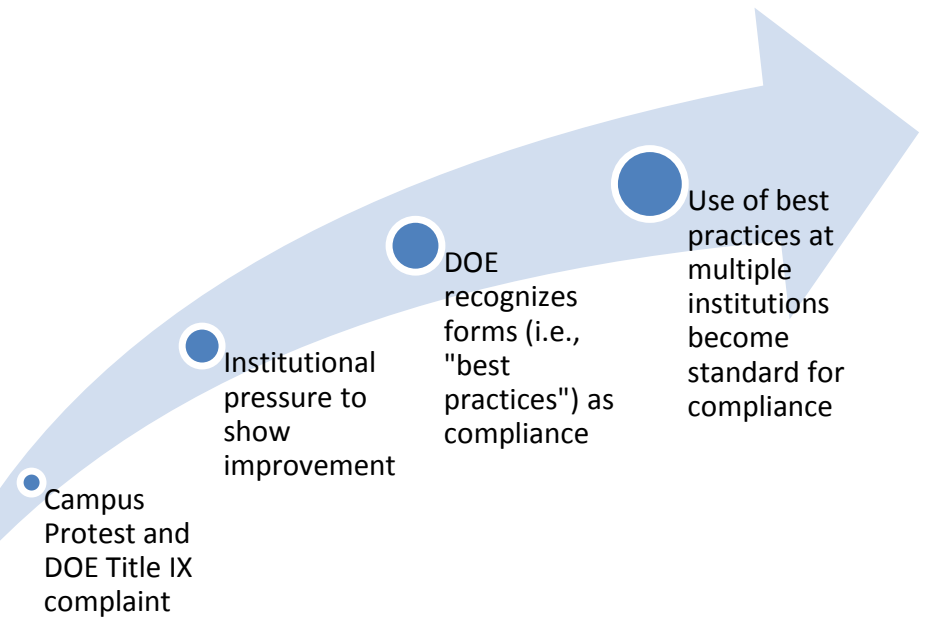

1. Figure 1: Legal Endogeneity and Low Expectations

Of course, to date only the first three points on the trajectory have been reached, and it remains possible that DOE will shift course and find ways to recognize and incentivize true prevention as well as indications that

168. See generally Megan R. Greeson et al., Improving the Community Response to Sexual Assault: An Empirical Examination of the Effectiveness of Sexual Assault Response Teams (SARTs), PSYCH. OF VIOLENCE (2015) [hereinafter SARTs].

169. Malcolm M. Feeley \& Jonathan Simon, The New Penology: Notes on the Emerging Strategy of Corrections and Its Implications, 30 CRIMINOLOGY 449, 453-54 (1992). See also supra Part III.A.2.c. 
attitudes and experiences are changing. But given the signs so far, ${ }^{170} \mathrm{my}$ pessimistic prediction seems more likely.

\section{Legal Endogeneity, Mansplaining, and Myth Accomodation}

While existing work documents the processes by which legal endogeneity influences judges over time, this case study demonstrates particular rhetorical strategies that work in concert with legality. Techniques in keeping with the pop-culture category of "mansplaining" "171 play a remarkable role in minimizing objections to policies and seem to overlap with miscognition (in the first case, male privilege accompanies omnipotent expertise, while in the latter, the privilege is located in legal credentials). ${ }^{172}$ But both proponents and opponents of policy reform shift their use of law as justification (recall for example the statements by General Counsel), ${ }^{173}$ revealing the continued ability of law to be everything to everyone, ${ }^{174}$ while maintaining deeply rooted myths about sexual violence. In this case, legal endogeneity in anticipation of possible DOE censure provided cover for tinkering with policies in ways that leave the deeply rooted myths that facilitate sexual violence untouched. ${ }^{175}$

\section{B. The Microlevel: Speaking Up}

While this case study focuses on what happens after one speaks up, it is worth recognizing the power and privilege that accompanies the ability to speak up. The campus protest with which I opened this Article was a

170. DOE investigators visited campus May 5-6, 2015. Zuvich, supra note 163. During the session open to faculty, investigators exhibited shockingly low thresholds for measuring the climate and the process on campus. For example, they asked, "How many of you know the definition of sexual assault?" Seeing a wide show of hands, they nodded their approval and took copious notes. The session continued this way.

171. Deborah Tudor, The Hysteric, the Mother, the Natural Gal: Male Fantasies and Male Theories in Films About Lincoln, JUMP CUT (2013), http://www.ejumpcut.org/archive/jc55.2013/TudorLincoln/text.html ("[T]he pop culture category of 'mansplaining,' a rhetorical form in which the world, including gender, is explained from the man's point of view, expressed as a transcendent, obvious truth. It is an organization of the world through masculine logic, which makes mansplaining a popular understanding of phallogocentrism.").

172. Thanks to Aya Gruber for prodding me to clarify this connection.

173. General Counsel, Open Hearing, supra note 3 (transcript at 18).

174. See generally Susan S. Silbey, After Legal Consciousness, 1 ANN. REV. L. \& SoC. SCI. 323 (2005).

175. See SARTs, supra note 168, at 1, 9 (describing how SART teams, which are nationally recognized as best practices, can range from active, interdisciplinary teams to loose affiliations which contain few of the practical components that are expected to accompany the SART model). 
powerful moment for many in the campus community, including students, staff, and faculty. ${ }^{176}$ This was apparent in reactions to the events that followed immediately after, ${ }^{177}$ as well as in reflections more than a year and a half past. As one student shared recently, "Just being a part of that, I felt the immense power of being in a group like thatsharing personal stories and being engaged in something bigger than myself." 178

With regard to my own campus experience (and my original invitation for the KU Law Review Symposium), I want to end by recognizing that if I did not have the support of colleagues, as well as the other experiences of privilege that will cushion me if I am censored or otherwise experience blowback, I would not have overcome my reluctance to speak up. ${ }^{179}$ I have new sympathy for all the people at Penn State, in the Catholic Church, and within the many other institutions and communities who know about gender-based violence, including sexual harassment, who are never effectively heard. ${ }^{180}$ We must empower not only victims, but also petty bureaucrats, as well as other relatively powerless people to pursue redress for these wrongs. We need transparency and honest communication about the harms that are caused, and the ways we can respond individually and as organizations and communities.

176. Carson, supra note 146

177. See Faculty Responds, supra note 8. Several faculty members shared with me privately how meaningful it was for them to hear from students who newly recognized these faculty members as a source of support.

178. Matt Moore, Standing Up: The Unyielding Drive of Harry Lewis, THE REVIEW (Dec. 8, 2015), http://udreview.com/standing-up-the-unyielding-drive-of-harry-lewis/. Moore further stated that,

[w]ithin his first month on campus, sexual harassment allegations [redacted name] were published in The Review, prompting a protest held on the steps of Memorial Hall, with students calling for transparency in the university's handling of sexual assault.

Lewis regards attending the protest that day as a formative moment in his development as a student activist.

Id.

179. I am profoundly grateful for the support, sometimes tempered with criticism and encouragement to shift my views and rethink my strategies, offered by my colleagues, and particularly, Anne Bowler, Susan Miller, Jennifer Naccarelli, Monica Shafi, Margaret Stetz, Gerry Turkel, Eric Rise, Aaron Kupchik, Ben Fleury Steiner, Ruth Fleury Steiner, Corey Shdaimah, Edith Kinney, Tamara Rice Lave and James Kimmel. I also thank Miles, Margaret, and Robert Leon for their patience during the past two years when this was often all I could talk about. Finally, little attention would have been drawn to these issues had student-journalists not stepped up to document our campus' struggles and to ask difficult questions. Thank you to the UD review, and to Cady Zuvich in particular.

180. See supra notes $26-27$ and accompanying text. 
I fear that these efforts will be undermined and obscured by the low expectations of legal endogeneity that view Title IX compliance as the reproduction of certain accepted "policies" but do nothing to challenge the underlying dismissal of sexual violence evident across so many realms.

\section{Challenging Bias and Assumptions}

This experience has connected with as well as challenged my $a$ priori assumptions about best practices in policies that address sexual violence. I have recognized in my body of work to date that I tend to cycle from outrage at a perceived wrong to a much more nuanced perspective. The opportunity to discover my own biases and to discover unexpected patterns and implications together make scholarship a creative and joyful experience. For me, this discovery has provided an antidote to burnout. Thus, I hope to facilitate recognition among scholars of both the impact of our biases and of the potential for upending them. 